\title{
Development of Child Education Tourism through Creative Dance in West Java-based Traditional Games
}

\author{
Rosarina Giyartini \\ Indonesian Education University \\ devicarasvati@gmail.com
}

\begin{abstract}
Todays, activities in Indonesia are surge massively in accordance with the changing times. Due to the urgent demand of the society, nature tourism, culture, history, religion, culinary, shopping, as well as education has thriving. A feasible solution to deal with such issue is by developing a child education business. Recreational activities, in which educational activities are included, aim to enhance the intelligence and creativity of tourism participants. This research intends to create an educational tourism model of children by redesigning the packaging of traditional game-based creative dance, without leaving behind the value of its origin. Hopefully, the results of this study will not only act as an interesting educational attraction of children, but also lead to the enhancement of the intelligence and creativity of children, and not to mention preserve the nation's culture.
\end{abstract}

Keywords: educational tour, creative dance, traditional game.

\section{INTRODUCTION}

West Java Province is known with its diverse and unique cultural arts. The uniqueness is ranging from the way they dressing, accent, traditional food (tutug oncom, peuyeum, loték, pépés, karédok, nasi timbel, dodol, galéndo, and others), musical instruments (angklung, rampak kendang, arumba, etc.), arts performing (sisingaan, kuda rénggong, tarawangsa, etc.), literary (pantun, etc.), drama (lénong and sandiwara), dance (mask dance, wayang dance, folk dance), to their traditional games (oray-orayan, péclé, sorodot gaplok, pelak cau, pérépét jéngkol, etc.). These have developed in West Java then lead to the reflection of the cultural roots behind it. The aforementioned-above arts are the result of the creativity of local communities, both, individually or in groups. Each region has its own unique characteristics that differentiate one and another. This then, in the coming years, can be developed into educational attractions of children, in addition to its function as an art and cultural assets in the province of West Java.

Development of educational tourism in West Java already started, but not with its educational tours that are devoted to children. Such development is different from other countries such as Japan and Thailand. The community's appreciation of the cultural arts in these other countries is remarkable. As an example, Japanese strongly uphold the values in every cultural art which has a traditional dress of Kimono. As a result, currently, Kimono became one of the most exclusive and mainly used on ceremonial occasions. Besides Kimono, there are other famous typical attractions in Japan such as Chadou (the famous tea ceremony), Ikebana (the art of flower arrangement) Bonsai (the art of dwarfing plants), Furoshiki, (the art of wrapping stuff that is very attentive to neatness and beauty), Tako (the art of kites is very rapidly growing).It does not surprisingly know the fact that those heritage still exist in Japan because parents continuously introduce those kinds of heritage to their children.It is also important to note that the Japanese government annually held a variety of cultural festivals in order to maintain their awareness. Khon, the dance theater from Thailand has performed with a very simple dance technique with the Ramayana story. Khon is shown with typical Thai culture with headdresses resembling a pagoda. Around the art building filled with display space of souvenir artisans, paintings, and traditional food. The profession of artists is more likely to have their future because they are given enough time and can be participated in the community. In Thailand the parental influence plays also pivotal role in introducing their culture [1].

Owing to this, it is worth preserving Indonesia as well as the art of the archipelago culture in early childhood, especially in elementary school age children. In this period, children will easily involve in wrapping tradition called kaulinan barudak. This study was conducted to excite the traditional game through the educational attractions of children packed with creative dance. It is also addressing inculcation the importance of understanding about the diversity art and culture from an early age, in order to foster the love of Indonesian homeland, as well as to increase tourist destinations in West Java Province that will sustain the economic needs of surrounding communities.

\section{METHOD}

This research uses data tracing method and data analysis that use various sources of information in its data collection, in order to give detailed description and depth information about the response of an event. The 
data in this research then is traced through 4 (four) ways: a) Study Libraries (library research), has a purpose to explore data related to the topic, both verbal data and pictorial data; b) Interviews, researchers collect data about the environment; c) Observation, namely data collection techniques by observing the state of the environment where research and socio-cultural conditions of the community; d) Documentation, used by researchers to support data acquisition during the study. The data analysis in this study refers to the theory of Creswell (153), as well as the ethnographic analysis of case studies comprising "detailed descriptions" of cases and their settings. Therefore, the method of data analysis of this study was conducted like Anton Bakker theory about the methodical elements in the research, namely description, analysis, interpretation, coherence, and synthesis [2]. Description is the effort to expose valid and accurate data to support the research topic. Analysis is a critical effort to discuss and examine the main concepts in this study. Interpretation is an attempt to explore the available data and reveal the meaning and nuance contained in it. Coherence and Synthesis are an effort to observe that the concept built is an interrelated system and an effort to gather opinions and views to find a more complete and complete unity, respectively.

\section{RESULTS}

Traditional games contain noble values that are very beneficial to life and character formation from an early age. Along with the development of Science and Technology (IPTEK), many traditional games of West Java are no longer played by children today. They switch to using gadgets as a means of play. Hence, attempts are needed to preserve the traditional game through creative dance and keep it from extinction. Furthermore, creative dance is tailored to fit the character of the child so that in the future era the traditional game is always recognizable, easily maintained, and remain sustainable.

Here is one example of a traditional West Java game called oray-orayan in Sundanese called kaulinan barudak oray-orayan, described by Atmadibrata [3] as the game that mimics a snake. The venue for the game is usually on a rather wide yard or in the field. This game can be done in 10-15 minutes, or up to many hours. Participants of this game is a group of boys, girls, or mixes with ages between 5-12 years with a number of players about 7-20 children.

Oray-orayan game using sentence pronunciation and asked in the form of a question and answer will be given by the players themselves. Here are the sentences.

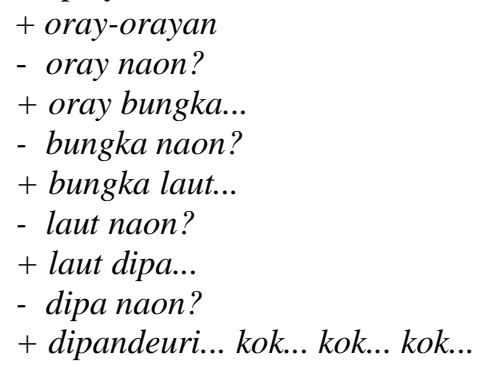

Some are sung as Koko Kuswara did as follows for oray-orayan.

+ oray-orayanluar léor mapay sawah,

- entong ka sawah paréna keur seudeung beukah,

+ oray-orayan luar léor mapay kebon,

- entong ka kebon, di kebon loba nu ngangon,

+ mending gé teu leuwi,

- di leuwi loba nu mandi,

+ saha nu mandi?

- anu mandina pandeuri... kok... kok... kok...

Here the translation of the song above:

+ oray-orayan along the rice fields,

- do not go to paddy fields are expanding,

+ oray-orayan creeping along the garden,

- do not go to the garden, in the many gardens that are shepherding,

+ Good diving,

- In the deep bath,

+ Who is bathing?

- The one in the back... kok... kok... kok..

The oray-orayan game pattern begins with the player making the rows lined up to form a snake. All the hands of the player hold the shoulder/waist of a friend in front of them, except the head of the snake (front) of his hands free. In forming the sequence, the player who has a tall body becomes the head of a snake, and increasingly toward the tail is occupied by small bodies.

Once all is ready, the game begins. The line is walking snaking like a snake creeping or singing or asking questions. As long as the line goes, the tail is always getting ready to dodge, because once it is over and the snake goes "kok... kok... kok...", then the snake will run around following the head trying to catch the tail. In this movement the player who becomes the body must follow the head of the moving snake. If the tail has been caught, then the tail must come out should not come into play. Furthermore, if the remaining 3 or 5 players, the game starts again from the beginning and the snake head is replaced by another.

The oray-orayan game contains values that can train dexterity, alertness and group skills (Atmadibrata, 1980/1981: 98). Kosasih also explained that the game oray-orayan loaded with the values of togetherness, because in the way of play must involve more than 5 people [4].

Oray-orayan game pattern has a clear cycle pattern and is exactly the same as the symbol of Ouroboros or Uroboros. Ouroboros is an ancient symbol depicting a serpent or a dragon eating its own tail. This symbol represents a self-reflection or cycle, especially something that means constant re-creation, the return of immortality, and other things which are regarded as cycles that start over as soon as they end, also symbolize the idea of a primordial unity associated with something existing or enduring before the beginning.

The attempt of the snake's head to catch its tail is a symbol of reaching for the absence of God who is physically absent, but he is there. The success of catching the tail is a success blend with immortality, the 
Supernatural. The perceived tailed player cannot come into play anymore as a symbol that those who have reached the stage of divinity, all his actions are by His will, all his lusts die, unless the will is one with Him. Similarly with this game, the "dead" tailed player will "live again" when the game starts again. From of the game pattern, there is the value of education, in the form of spirituality education and the following educational value.

1. Aesthetics, it can be seen from the snaking motion pattern, the order of placement of players, and the choice of words in song poetry

2. Ethics/morals, game oray has rules must be obeyed;

3. Interpersonal intelligence, players have to to be responsible for themselves and cooperate according to their respective roles, i.e. as leader (snake head), member (body of snake), and subject of target (snake tail);

4. Spatial-visual rigidity, players are stimulated to dominate the game room because it always has to hunt the tail;

5. Logical-mathematical intelligence, the player is stimulated to always remember the number of tails that have been captured;

6. Kinesthetic intelligence, players must be compact in movement (so that the body of the snake does not break), the player must also always be agile move in hunting the tail;

7. Compactness and solidarity, the serpent performers faithfully follow the head of a snake in an attempt to catch the tail;

8. The translated song's lyrics above along with given question and answer sentence have the same meaning, the question is always related to the answers given, so it is also related to obstacles and solutions to overcome them. The educational aspect contained in the oray-orayan poem is as follows.

9. Linguistic-verbal intelligence, players must master the language/sentence/poem used;

10. Musical-rhythmic intelligence, players must align motion with sung song;

The various benefits from the traditional game orayorayan can positively improve the intelligence and creativity of children as described above. Movements made during oray-orayan play the basis of the creation of modification motion to create a creative dance made by children. Associated with it, then educational tour becomes a necessary thing. An educational tour package wrapped in cultural preservation becomes very interesting, children are invited to play and create a dance. Educational tours packages are packed into a package of fun activities can cause a new atmosphere and will add new knowledge also for children. Children are invited to play together while developing a variety of intelligence and creativity within themselves and interspersed with making a dance of their own work. This can increase self-confidence and self-esteem of children. It is undeniably that educational tours will bring more, benefits and other advantages for the development of children themselves, indirectly children come to preserve the culture of West Java.

\section{CONCLUSION}

Based on the above explanation, there are 2 (two) conclusions that can be taken; 1) Traditional Indonesian art in West Java need to be preserved by the generation of the nation, especially children from an early age in order to maintain and not eroded the modernization of culture outside their place; 2) Educational tour is needed as a provision of knowledge and strengthening various intelligences through fun way, in the form of vacation package, play, study, and work from traditional game which is packed into creative dance.

\section{REFERENCES}

[1] Atmadibrata, Enoch. People's Games West Java Region. Jakarta: Ministry of Education and Culture, Directorate of History and Traditional Values. Project Inventory and Documentation of Regional Culture. 1980-1981,

[2] Caturwati, Endang. Et al., Ed. Performing Arts and Challenges of the Age, Speech inauguration of Professorship at Sekolah Tinggi Seni Indonesia Bandung, March 22, 2008. 2008.

[3] Cresswel, John W.Qualitative Inquiry and Research Design: Choosing Among Five Tradition. London: SAGE Publications. 1998.

[4] Ediyono, Suryo. "Martial Art of Pencak Silat in the Formation of Human Self-concept of Java (Study of Pencak Silat Pencak Silat Brotherhood Seti Hati Ternate)". Dissertation to obtain Doctoral degrees in Philosophy Department of Humanities at Universitar Gajah Mada Yogyakarta. 2005.

[5] Gillbert, Anne Green. Creative Dance For All Age: A Conceptual Approach. Reston: The American Alliance for Health, Phsycal Education, Recreation, and Dance. 1992.

[6] Giyartini, Rosarina"The Concept of Creative Dance Learning at Dasae School: from Children, by Children, and to Children. Thesis for Taking a Master Degree in Education of Education Program of Dance Education UPI Bandung. 2007.

[7] Giyartini, Rosarina. "Creative Dance: The Concept of Learning in Primary Schools: from Children, by Children, to Children" in Tati Narawati, Rita Mulyartini, Zakaria S., Soeteja (peny.), Education of Arts and Social and Cultural Change. Bandung: SPS UPI. 2008.

[8] Giyartini, Rosarina."Saman Gayo Dance: Value of Philosophy and Learning Strategy in Primary School." Independent research, UPI. 2011.

[9] Kosasih, Dede. (2009). "Etnopedagogi in the Sunda Sundanese Messenger" in Pikiran Rakyat, May 23, 2009. 2009. 